ReVISTA de BIOLOGía TROPICAL

\title{
Anomalous coloration of a yellow tail damselfish Stegastes arcifrons (Actinopterygii: Pomacentridae) at Isla del Coco National Park, Costa Rica
}

\author{
Andrés Beita-Jiménez ${ }^{1,2} \&$ Juan José Alvarado ${ }^{1,2,3}$ \\ 1. Escuela de Biología, Universidad de Costa Rica; abeitaj@gmail.com \\ 2. Centro de Investigación en Ciencias del Mar y Limnología, Universidad de Costa Rica; juanalva76@yahoo.com \\ 3. Museo de Zoología, Universidad de Costa Rica
}

Received 24-II-2015. Corrected 09-V-2015. Accepted 28-V-2015.

\begin{abstract}
Coloration patterns of reef fishes are an important trait for mediating intra and interspecific interactions, as well as for taxonomic identifications. Here we report a specimen of Stegastes arcifrons that presented a previously unobserved and anomalous color variation on a coral reef at Isla del Coco, Pacific Costa Rica. This color variation is known as xanthism and has been reported in some damselfishes, usually associated with genetic anomally. Rev. Biol. Trop. 64 (Suppl. 1): S197-S199. Epub 2016 February 01.
\end{abstract}

Key words: reef fish, Tropical Eastern Pacific, color pattern, xanthism.

Coloration is an essential attribute in reef fish life history. Color patterns are important elements of inter- and intra-specific species interactions (e.g., predation, competition, sexual selection, life stage identification), learning and communication (Siebeck, Wallis, \& Litherland, 2008; Leclercq, Taylor, \& Migaud, 2010). Coloration patterns relate to the economic value of reef fish species used in the ornamental trade, with rare patterns increasing value (Leclercq et al., 2010). Furthermore, it is a trait widely used by taxonomists for species description and identification (Souza, Ilarri, Medeiros, Sampaio, \& Floeter, 2011). The color in damselfish of the genus Stegastes is determinant in taxonomic classification and has traditionally been considered having a conservative morphology, however color variations have been reported for some species (Robertson, \& Allen, 2008; Souza et al., 2011; Palacios-Salgado, \& Rojas-Herrera, 2012). The purpose of this note is to report an anomalous color variation of a yellow tail damselfish Stegastes arcifrons (Heller, \& Snodgrass, 1903) on a coral reef at Isla del Coco National Park, Pacific Costa Rica.

Isla del Coco (also known as Cocos Island) is an oceanic island in the Eastern Tropical Pacific Ocean, about $500 \mathrm{~km}$ from mainland Costa Rica. It was declared a National Park in 1978, a UNESCO World Heritage Site in 1997, and a Ramsar site in 1998 (Cortés, 2012). Stegastes arcifrons is a territorial damselfish known only from Isla del Coco, Galápagos Archipelago, Isla de la Plata, Malpelo Island and Isla Gorgona (Robertson, \& Allen, 2008). This species is the most common on reefs surrounding Isla del Coco, while Stegastes acapulcoensis (Fowler, 1944), Stegastes beebei (Nichols, 1924) and Stegastes flavilatus (Gill, 1862) also are found there (Cortés, 2012; Friedlander et al., 2012; Alvarado et al., 2015).

Underwater observations were made during a SCUBA dive at Manuelita Coral Garden, a reef site on the north side of Isla del Coco $\left(5^{\circ} 33^{\prime} 42.7^{\prime \prime} \mathrm{N}-87^{\circ} 2^{\prime} 48.9^{\prime \prime} \mathrm{W}\right)$ on July 14, 2013. A photographic record was made of a single specimen of $S$. arcifrons with unusual 

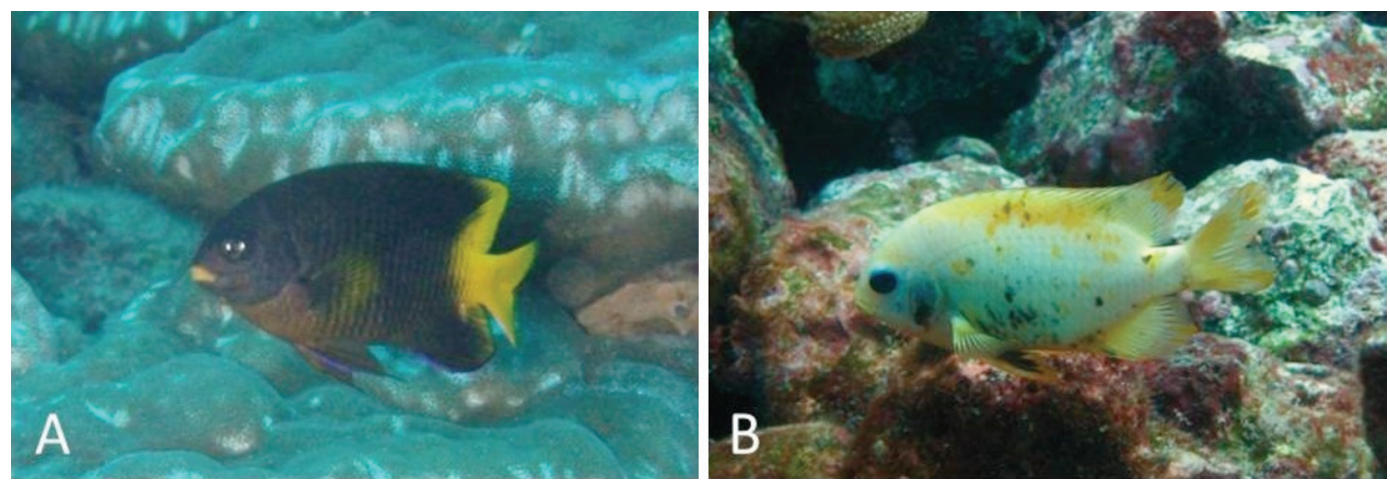

Fig. 1. (A) Adult Stegastes arcifrons with common coloration; (B) different color pattern in S. arcifrons observed at Isla del Coco, Costa Rica. Photos by A. Ayala (A) and C. Sánchez (B).

coloration. Taxonomic identification was confirmed according to available literature (Allen, \& Woods, 1980; Robertson, \& Allen, 2008). The observations of this fish were carried out along reef fish monitoring transects as part of a regional project that asses the composition and structure of coral reef ecosystems at Isla del Coco. Transects in which the fish were observed were $10 \mathrm{~m}$ long by $5 \mathrm{~m}$ wide and $5 \mathrm{~m}$ high (Alvarado et al., 2015).

Stegastes arcifrons commonly exhibits a dark brown coloration on the head and a lighter torso, yellow lips and a bright yellow caudal fin (Fig. 1A; Robertson, \& Allen, 2008). In contrast, the specimen observed at Manuelita Coral Garden presented a pale coloration across most of the body with black spots of variable size and position. While the characteristic yellow lips were present, irregular shaped patches of yellow occurred along the upper dorsal surface and on the dorsal, caudal, pectoral and anal fins. The pelvic fins exhibited a black inner part surrounded by an orange line (Fig. 1B). This specimen was an adult of approximate $10 \mathrm{~cm}$ in total length, appeared healthy and was not guarding a nest, at least in any obvious way (i.e., defending a local territory and returning to a nest site).

The color abnormality shown in the specimen of $S$. arcifrons is known as xanthism, and it is usually caused by a genetic anomaly (Luiz-Júnior, 2003; Palacios-Salgado,
\& Rojas-Herrera, 2012). This color variation is uncommon in coastal populations, but can be frequent in small or isolated populations due to inbreeding and consequent expression of recessive traits (Luiz-Júnior, 2003; Palacios-Salgado, \& Rojas-Herrera, 2012). Xanthic coloration in damselfishes has been reported in S. acapulcoensis and Microspathodon bairdii (Gill, 1862) from the Eastern Tropical Pacific (Robertson, \& Allen, 2008; Palacios-Salgado, \& Rojas-Herrera, 2012) and in Stegastes pictus (Castelnau, 1855) from the Western Atlantic (Souza et al., 2011).

The occurrence of the color variation as described, at least to date, is anomalous. Recent studies reported $S$. arcifrons occurred at a mean density ( \pm standard deviation) of $1.86 \pm 1.86$ ind per $\mathrm{m}^{2}$ in the site visited for the report herein and occurred at all of study sites around Isla de Coco (Friedlander et al., 2012; Alvarado et al., 2015). No reports of this or any other anomalous color patterns were reported, although tracking this particular attribute was not the objective of those studies.

\section{ACKNOWLEDGMENTS}

We want to thank A. Ayala and C. Sánchez for the pictures used in this paper. We appreciate the help and financial support from Conservation International, Undersea Hunter Group, CIMAR-UCR and park rangers of Isla 
del Coco. This project has permission 0652013-SINAC, and it is register in FUNDEVI (2739-019) and Vice-Rectory for Research at the University of Costa Rica (808-B3-503). Peter Auster, Jorge Cortés and two anonymous reviewers provided helpful comments that improved the manuscript.

\section{RESUMEN}

Coloración anormal en la damisela cola amarilla Stegastes arcifrons (Actinopterygii: Pomacentridae) en el Parque Nacional Isla del Coco, Costa Rica. Los patrones de coloración son características importantes en peces de arrecife, ya que estos determinan las relaciones inter e intra específicas, también son de gran utilidad para la identificación taxonómica. Aquí se reporta un espécimen de Stegastes arcifrons en un arrecife coralino de la Isla del Coco, en el Pacífico de Costa Rica, el cual presentaba una coloración anómala y que no había sido observada previamente. Esta variación de color es conocida como xantismo y ha sido reportada en otras damiselas, usualmente está asociada con anomalías genéticas.

Palabras clave: peces de arrecife, Pacífico Oriental Tropical, patrón de coloración, xantismo.

\section{REFERENCES}

Allen, G., \& Woods, L. (1980). A review of the damselfish genus Stegastes from the Eastern Pacific with the descriptions of a new species. Records of the Western Australia Museum, 8(2), 171-198.

Alvarado, J. J., Beita-Jiménez, A., Mena, S., FernándezGarcía, F., Guzmán, A. G., \& Cortés, J. (2016).
Ecosistemas coralinos del Área de Conservación Marina Isla del Coco, Costa Rica: análisis estructural y temporal. Revista de Biologia Tropical, 64(Supplement 1), 153-175.

Cortes, J. (Ed.) (2012). Investigaciones marinas en el Parque Nacional Isla del Coco, Costa Rica. Revista de Biología Tropical, 60(Supplement 3), 1-392.

Friedlander, A. M., Zgliczynski, B. J., Ballesteros, E., Aburto-Oropeza, O., Bolaños, A., \& Sala, E. (2012). The shallow-water fish assemblage of Isla del Coco National Park, Costa Rica: structure and patterns in an isolated, predator-dominated ecosystem. Revista de Biología Tropical, 60(Suplement 3), 321-338.

Leclercq, E., Taylor, J. F., \& Migaud, H. (2010). Morphological skin colour changes in teleosts. Fish and Fisheries, 11(2), 159-193.

Luiz-Júnior, O. (2003). Colour morphs in a Queen Angelfish Holacanthus ciliaris (Perciformes: Pomacanthidae) population of St. Paul's Rocks, NE Brazil. Tropical Fish Hobbyist, 51(5), 82-90.

Palacios-Salgado, D. S. \& Rojas-Herrera, G. A. (2012). Partial xanthism in a specimen of Acapulco major, Stegastes acapulcoensis (Teleostei: Pomacentridae), from the Tropical Eastern Pacific. Pan-American Journal of Aquatic Sciences, 7(3), 175-177.

Robertson, D.R. \& Allen, G.R. (2008). Shorefishes of the tropical Eastern Pacific online information system. Retrived from www.stri.org/sftep

Siebeck, U. E., Wallis, G. M., \& Litherland, L. (2008). Colour vision in coral reef fish. Journal of Experimental Biology, 211(3), 354-360.

Souza, A. T., Ilarri, M. I., Medeiros, P. R., Sampaio, C. L. S., \& Floeter, S. R. (2011). Unusual colour patterns of territorial damselfish (Pomacentridae: Stegastes) in the south-western Atlantic. Marine Biodiversity Records, 4, e101. doi: 10.1017/S1755267211001035. 
